\title{
エナメル上皮腫に対する外科療法の治療成績と 再発に関する臨床的検討
}

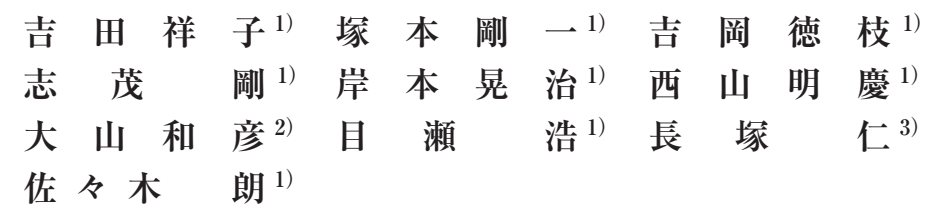

要旨：エナメル上皮腫の治療法については論議のあるところである。当科においては, 周囲骨の穿孔がないかもしく はわずかであれば, 保存的外科療法一骨面削除と凍結療法を併用した摘出術一を基本的に選択している。当論文では, 当科開設の 1982 年から 2007 年までの 25 年間に経験したエナメル上皮腫 50 例，特に再発症例について検討を行った。

50 例の手術の内訳は, 摘出術 12 例, 摘出と骨面削除または骨面削除掞よび凍結療法（摘出＋補助療法）が 21 例, 顎骨切除（辺縁切除と区域切除）が 17 例であった。再発は 6 例であり（再発率： $12 \%$ ), 摘出術に 5 例（再発率： $42 \%$ ), 摘出＋補助療法に 1 例（再発率： $5 \%$ ）認めた。顎骨切除術は再発を認めなかった。摘出と顎骨切除との間お よび, 摘出と摘出 + 補助療法との間に再発率に関し有意差を認めた。

以上より，エナメル上皮腫の保存的外科療法において，骨面削除と凍結療法は有用であることが示唆された。

キーワード : エナメル上皮腫, 再発, 臨床統計的検討, 保存的外科療法

\section{緒言}

エナメル上皮腫は顎骨に発生する代表的な良性歯原性 腫瘍で ${ }^{1)}$, 治療法としては根治性を重視した䫟骨切除法 や $^{2-5)}$, 摘出術, 開空・反復処置法といった靧骨の機能温 存を目的とした保存的外科療法 ${ }^{6-13)}$ がある。とくに後者で は根治性の観点から, 骨面削除, 凍結療法 ${ }^{14)}$ やカルノア 液による化学療法 ${ }^{15-17)}$ 等工夫がなされている。当科にお いては, エナメル上皮腫に対する治療として, 摘出術に骨 面削除と凍結療法を併用した保存的外科療法を基本的に選 択し, 広範囲の軟組織進展症例や上顎上方㧍よび下顎下縁 への進展が著しい症例に対し, 顎骨切除術を選択してい る。今回当科で経験したエナメル上皮腫について臨床病理 学的分析を行い, 特に再発症例について検討したので報告 する。

\section{対象および方法}

\section{1. 対象}

対象は, 岡山大学病院口腔外科（病態系）が開設された

\footnotetext{
1) 岡山大学大学院医歯薬学総合研究科口腔頑顔面外科学分野 (主任：佐々木 朗教授)

2) 赤穂はくほう会病院歯科口䏶外科（主任：大山和彦部長）

3) 岡山大学大学院医歯薬学総合研究科口脘病理学分野 (主任：長塚 仁教授)

〔受付 : 2009 年 8 月 3 日, 受理 : 2010 年 1 月 19 日〕
}

1982 年 4 月から 2007 年 3 月までの 25 年間に当科を受診し, 評価に必要な資料を保有していたエナメル上皮腫 1 次症例 50 例である。

\section{2. 方法}

対象症例を, 特に再発症例について生検の有無と術前診 断別, 治療法別に分類, またX 線学的, 病理組織学的所 見をもとに再発との相関の検討を行った。統計的検討には Fisher’s exact test を用い, $\mathrm{p}<0.05$ を有意差ありとした。

\section{結 果}

\section{1. 年齢，性別，部位別分布}

初診時年齢を年代別にみると，30 歳代が 10 例（20\%） と最も多く，10歳代が 9 例（18\%）と続いた。平均年齢 は 40.2 歳で, 最低年齢 11 歳, 最高年齢 71 歳であった。 性別では男性 34 例（68\%），女性 16 例（32\%）と男性に 多く, 男女比は $2.1: 1$ であった（表 1)。発生部位は上顎 3 例 $(6 \%)$ ，下顎 47 例（94\%）で下顎に多く認められた。

\section{2. 術前診断と再発との関係}

術前診断でみると（表 2)，エナメル上皮腫と診断した ものは 46 例で, 生検を行った 42 例中エナメル上皮腫の病 理組織診断に至ったものが 38 例, 確定診断に至らなかっ たがエナメル上皮腫の疑いが 4 例であった。残り 4 例は術 前生検を行っていなかった。一方, 歯原性または䪽骨襄胞 の術前診断で術前生検を行わずに手術となったものは 4 例 であった。生検の有無に関わらず術前診断をエナメル上皮 
腫として治療を行った 46 例中 3 例 $(6.5 \%)$ に再発を認めた。 一方，囊胞と術前診断し治療を行った 4 例中 3 例（75\%） に再発を認めた $(\mathrm{p}<0.005)$ 。

\section{3. 治療法と再発との関係}

術式の内訳は, 摘出 12 例（再発 5 例, 再発率 $42 \%$ ), 摘出十骨面削除もしくは摘出十骨面削除＋凍結療法（以 下, 摘出 + 補助療法と記載) 21 例 (再発 1 例, 再発率 $5 \%$ ), 顎骨切除（上顎骨：部分切除.下顎骨：辺縁および区域 切除） 17 例（再発なし）であった（表 3）。摘出と顎骨切 除の間で $(\mathrm{p}<0.01)$, 摘出と摘出 + 補助療法との間で $(\mathrm{p}$

表 1 年齢・性別と再発の関係

\begin{tabular}{cllc}
\hline 年齢(歳) & 男性 & 女性 & 計 \\
\hline $10 \sim 19$ & 4 & $5(2)$ & $9(2)$ \\
$20 \sim 29$ & 5 & $3(1)$ & $8(1)$ \\
$30 \sim 39$ & 9 & 1 & 10 \\
$40 \sim 49$ & $5(2)$ & 1 & $6(2)$ \\
$50 \sim 59$ & $5(1)$ & 2 & $7(1)$ \\
$60 \sim 69$ & 5 & 3 & 8 \\
$70 \sim 79$ & 1 & 1 & 2 \\
\hline 計 & $34(3)$ & $16(3)$ & $50(6)$ \\
\hline & & $(\quad)$ 内は再発症例
\end{tabular}

$<0.02)$, 再発率において有意差を認めた。摘出 + 補助療 法と顎骨切除の間には有意差は認められなかった。

摘出 + 補助療法のうち 4 例は生検後開空処置を行った 症例である。1 例は全身疾患の関係で全身麻醉施行可能と なるまで手術待機となったため, 結果的に開空処置となっ た。2 例は X 線上単房性で, 生検時の所見で unicystic 型 と診断し開空処置を行ったが腫瘍が増大傾向にあること を確認した時点で手術を行った。摘出物病理標本は solid/ multicystic 型であった。残り 1 例は術前に unicystic 型と 診断し, 摘出物病理検査結果も unicystic 型であったが, 開空処置を行ったものの, 腫瘍の縮小を認めなかったため 早期に手術を行った。開密期間は 4 か月から 1 年であった。

年齢との関係では, 術式別の平均年齢は, 摘出 41.3 歳 (囊胞と術前診断した 4 例を除く), 摘出 + 補助療法 31.1 歳, 顎骨切除 49.5 歳であった。生検後開空処置を行った 4 例の平均年齢は 30.8 歳であった。

\section{4. $X$ 線学的所見と再発との関係}

再発症例について, 画像所見をもとに病巣の形態を, 単 房性, 多房性, 蜂巣状, 石畧泡状の 4 つに分類した ${ }^{18,19)}$ 。 50 例中単房性のものが 29 例（58\%）で最も多く, 多房性 14 例 $(28 \%)$, 石眕泡状 7 例（14\%）であった。再発した 6 例は単房性 3 例, 多房性 2 例, 石畧泡状 1 例であった。 各群中における割合はそれぞれ $10 \%, 14 \%, 14 \%$ でった。

表 2 術前診断と再発の関係

\begin{tabular}{|c|c|c|c|c|}
\hline 術前診断 & 生検結果 & 非再発症例数 & 再発症例数 & \\
\hline \multirow{4}{*}{ エナメル上皮腫 } & エナメル上皮腫 & 36 & 2 & \\
\hline & $\begin{array}{l}\text { 確定診断困難 } \\
\text { (エナメル上皮腫疑い) }\end{array}$ & 4 & 0 & \\
\hline & 生検なし & 3 & 1 & \\
\hline & 計 & 43 & 3 & $\neg$ \\
\hline 霅胞 & 生検なし & 1 & 3 & ]$^{*}$ \\
\hline
\end{tabular}

表 3 治療法と再発の関係

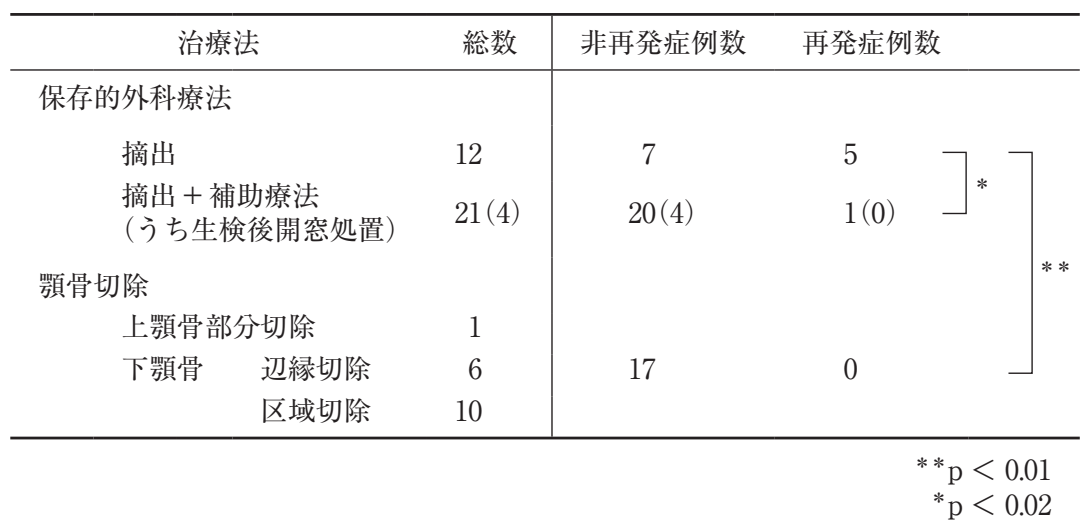


表 4 治療法および病理組織と再発との関係

\begin{tabular}{|c|c|c|c|c|c|c|c|c|}
\hline & \multicolumn{4}{|c|}{ solid/multicystic } & \multicolumn{2}{|c|}{ unicystic } & \multirow[b]{2}{*}{ desmoplastic } & \multirow[b]{2}{*}{ 計 } \\
\hline & follicular & plexiform & $\begin{array}{l}\text { follicular } \\
+ \text { plexiform }\end{array}$ & その他 & luminal & mural & & \\
\hline 摘出 & $1(2)$ & $3(6)$ & $1(1)$ & $0(1)$ & $0(1)$ & $0(0)$ & $0(1)$ & $5(12)$ \\
\hline 摘出 + 補助療法 & $0(4)$ & $1(8)$ & $0(1)$ & $0(2)$ & $0(3)$ & $0(3)$ & $0(0)$ & $1(21)$ \\
\hline 顎骨切除 & $0(5)$ & $0(5)$ & $0(2)$ & $0(3)$ & $0(1)$ & $0(0)$ & $0(1)$ & $0(17)$ \\
\hline 計 & $1(11)$ & $4(19)$ & $1(4)$ & $0(6)$ & $0(5)$ & $0(3)$ & $0(2)$ & $6(50)$ \\
\hline
\end{tabular}

表 5 再発症例一覧

\begin{tabular}{|c|c|c|c|c|c|c|c|c|c|c|c|}
\hline & 性別 & 年齢 & 発生部位 & $\mathrm{X}$ 線像 & 生検 & $\begin{array}{c}\text { 術前 } \\
\text { 臨床診断 }\end{array}$ & 病理組織所見 & 治療法 & $\begin{array}{c}\text { 再発まで } \\
\text { の期間 }\end{array}$ & $\begin{array}{c}\text { 再発後 } \\
\text { 最終手術法* }\end{array}$ & その後の経過 \\
\hline 1 & 女 & 18 & 上顎臼歯部 & 単房性 & 無 & 顎骨霊胞 & $\begin{array}{l}\text { solid/multicystic } \\
\text { plexiform }\end{array}$ & 摘出 & 6 年 & 顎骨切除 & $\begin{array}{l}4 \text { 年 } 9 \text { か月後 } \\
\text { 経過良好 }\end{array}$ \\
\hline 2 & 男 & 43 & 上顎臼歯部 & 単房性 & 無 & 顎骨霅胞 & $\begin{array}{l}\text { solid/multicystic } \\
\text { follicular + plexiform }\end{array}$ & 摘出 & 5 年 & 顎骨切除 & $\begin{array}{l}8 \text { 年 } 4 \text { か月後 } \\
\text { 経過良好 }\end{array}$ \\
\hline 3 & 男 & 28 & $\begin{array}{l}\text { 下顎臼歯部 } \\
\text { 下顎枝 }\end{array}$ & 単房性 & 無 & $\begin{array}{l}\text { 含歯性 } \\
\text { 囊胞 }\end{array}$ & $\begin{array}{l}\text { solid/multicystic } \\
\text { plexiform }\end{array}$ & 摘出 & 2 か月 & $\begin{array}{l}\text { 摘出 + 骨面削除, } \\
\text { 凍結療法 }\end{array}$ & $\begin{array}{l}\text { 転居のため } \\
\text { 経過追えず }\end{array}$ \\
\hline 4 & 女 & 19 & 下顎臼歯部 & 石鈿泡状 & 無 & $\begin{array}{l}\text { エナメル } \\
\text { 上皮腫 }\end{array}$ & $\begin{array}{l}\text { solid/multicystic } \\
\text { plexiform }\end{array}$ & $\begin{aligned} & \text { 摘出 } \\
+ & \text { 骨面削除 }\end{aligned}$ & 8 年 2 か月 & $\begin{array}{l}\text { 摘出 + 骨面削除, } \\
\text { 凍結療法 }\end{array}$ & $\begin{array}{l}6 \text { 年後 } \\
\text { 経過良好 }\end{array}$ \\
\hline 5 & 男 & 47 & 下顎臼歯部 & 多房性 & 有 & $\begin{array}{l}\text { エナメル } \\
\text { 上皮腫 }\end{array}$ & $\begin{array}{l}\text { solid/multicystic } \\
\text { plexiform }\end{array}$ & 摘出 & 7 年 & $\begin{array}{l}\text { 摘出 }+ \text { 骨面削除, } \\
\text { 凍結療法 }\end{array}$ & $\begin{array}{l}2 \text { 年後 } \\
\text { 経過良好 }\end{array}$ \\
\hline 6 & 男 & 50 & 下顎臼歯部 & 多房性 & 有 & $\begin{array}{l}\text { エナメル } \\
\text { 上皮腫 }\end{array}$ & $\begin{array}{l}\text { solid/multicystic } \\
\text { follicular }\end{array}$ & 摘出 & 2 年 4 か月 & 顎骨切除 & $\begin{array}{l}6 \text { 年 } 2 \text { か月後 } \\
\text { 経過良好 }\end{array}$ \\
\hline
\end{tabular}

*再発後再手術が複数回の場合最終手術法を記載

\section{5. 病理組織学的所見と再発との関係}

摘出物病理標本を, 2005 年に改訂された歯原性腫瘍 の WHO 分類 ${ }^{20)}$ に基づき solid/multicystic 型（follicular, plexiform, 両者混在型), unicystic 型 (luminal, mural 型), desmoplastic 型に分類した（表 4)。組織型別に分類する と, 再発例はすべて solid/multicystic 型で (40 例中 6 例), follicular 型 1 例, plexiform 型 4 例, 両者混在型 1 例, 各 群中における割合はそれぞれ $9 \%, 21 \%, 25 \%$ あっった。 術式別に検討すると, 摘出での再発 5 例は solid/multicystic 型の follicular 型 1 例, plexiform 型 3 例, 両者混在型 1 例であった。摘出 + 補助療法で再発の 1 例は solid/multicystic 型の plexiform 型であった。

\section{6. 再発症例経過}

以下に再発症例 6 例（1～6）の詳細を記す（表 5)。 症例 $1 ， 2 ， 3$ は囊胞の術前臨床診断で手術が行われ, 骨 面削除，凍結療法は行っていなかった。また， 3 例とも隣 接歯の術中抜歯は行っていなかった。症例 1 は, その後上 顎洞上方へ進展し， 2 度の上顎骨部分切除術を行ったが, 早期に対応でき腫瘍は制御できた。症例 2 は, 再発時に上 顎骨の部分切除術を行ったが，その後経過良好である。下
顎に発生した症例 3 は, 再発時隣接歯を抜歯し, 骨面削除 と凍結療法併用の摘出術を施行したが, 経過に関しては転 居のため確認し得ていない。

症例 4 は，エナメル上皮腫の臨床診断のもと，症例 5 , 6 は, 生検にて術前にエナメル上皮腫と確定後, 摘出術を 施行した。症例 4 は 8 年 2 か月後, 症例 5 は 7 年後に再発 を認めた。骨面削除と凍結療法併用の摘出術を行うことに よって，その後それぞれ 6 年および 2 年の経過観察期間中, 再発は認めなかった。症例 6 は, 再発後, 摘出術十骨面 削除を施行したが，制御が困難で顎骨の区域切除を行い, その後は経過良好であった。

\section{考察}

エナメル上皮腫は顎骨に発生する代表的な良性歯原性腫 瘍 ${ }^{1)}$ で，2005 年 WHO 歯原性腫瘍の新分類にそった柴原 ら 21）の報告でも，発生頻度は $29 \%$ と多くを占めていた。 組織像は臨床像とともに多様で，しばしば再発することが 知られている2)。また，まれではあるが悪性の経過をとる 場合もある ${ }^{22,23)}$ 。エナメル上皮腫の治療法については，本 
邦に抢いても保存的外科療法と顎骨切除の選択には論議の あるところで ${ }^{222}$ ，その治療方針には施設間で差があるの が現状といえる24-28)。

当科においては, 腫瘍の進展が著しいあるいは軟組織進 展症例以外は年齢に関係なく基本的には保存的外科療法を 選択している。ただし, 若年者に関しては顎骨の成長を考 慮して摘出後の骨削除は最小限にしている。そして, 当科 の治療法別でみると, 顎骨切除と比較して摘出および摘出 + 補助療法の適応年齢が低いという結果となった。

再発の原因として, 小崎ら ${ }^{3)}$ は腫瘍の䫈骨内への浸潤 増殖と不完全な手術による腫瘍組織の残存であると述べ, 治療法として顎骨切除を推奨している。Carlson ら ${ }^{4)}$ は solid/multicystic 型の治療法は切除で, 安全域を X 線像 から $10 \sim 15 \mathrm{~mm}$ 確保する理由として, 腫瘍の病理学的境 界は, X 線的境界より平均 $4.5 \mathrm{~mm}$ 浸潤していることをあ げている。そして, 保存的外科療法後に頭蓋へ進展し, 死 の転帰となった症例を提示し, エナメル上皮腫は細胞学的 には良性といえども，とくに solid/multicystic 型は侵襲性 の高い性質から, 保存的外科療法を先行し, 再発時根治的 外科療法を検討するという考え方は誤りであると述べてい る。畑田ら ${ }^{2)}$ は, 再発を繰り返し手術的侵襲を何回も加え ることで悪性転化をきたし死亡する転帰をとる症例もある ことから, 治療法に関しては根治的に行うことが望ましい としている。

これに対して，下顎に扔ける保存的外科療法について， Sachs $^{6)}$ は, 限局性の下顎エナメル上皮腫を切除する際, 安全域をX 線的境界より画一的に $10 \sim 15 \mathrm{~mm}$ に設定し 切除する方法は, 切除不足または切除過剩それぞれのケー スが起こりうる可能性があるとしている。これに加え健全 な舌側骨も切除してしまうことになるので, 腫瘍を除去後 直視下で，腫瘍と接していた残存骨面を $3 \mathrm{~mm}$ 程度削除す る方法を推奨している。また Sampson ら ${ }^{7)}$ は下顎エナメ ル上皮腫に抢いて骨穿孔がなければ, 掻爬と凍結療法の併 用療法は有用であるとし, 森田ら ${ }^{8)}$ も, 再発の防止策とし て腫瘍を摘出後，周囲骨を掻爬し，さらに骨面をバーにて 平滑にし，凍結療法を行う際は腫瘍と接していた周囲骨全 面を一定の深さまで効果が及ぶように凍結すると述べてい る。Curi ら ${ }^{14)}$ は solid/multicystic 型のエナメル上皮腫は 凍結療法を行うことによって再発率を減らすことができる としている。自験例の凍結療法の適応については, 現在の ところ腫瘍の摘出, 骨面削除後, 小規模の骨欠損について も骨面と同様に凍結療法で対応している（写真 1$)$ 。保存 的外科療法に打いて, 摘出 + 補助療法 21 例は再発は 1 例 のみで良好な治療成績を示し, 骨面削除と凍結療法の併用 が有効であると考えられた。Salmassy ら ${ }^{29)}$ は病巣が下顎 下縁より $10 \mathrm{~mm}$ 以下のところまで進展している場合は凍 結療法を含む手術後病的骨折の可能性が大きくなるとして

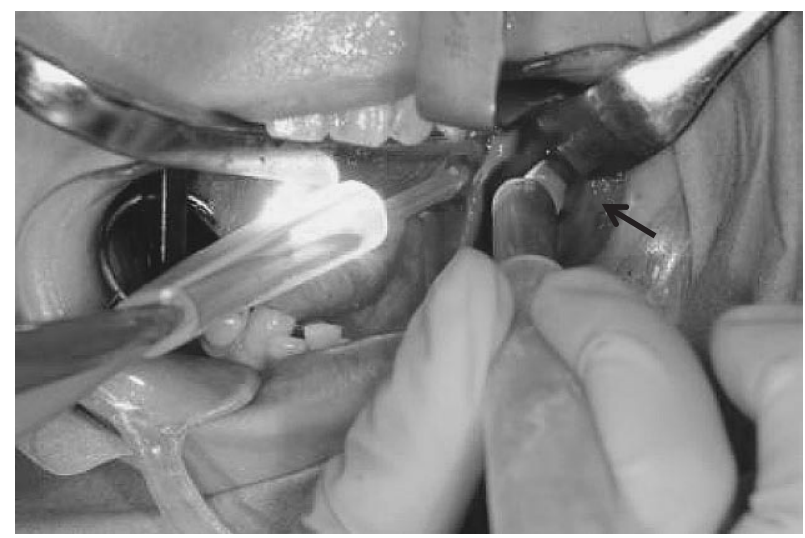

写真 1 凍結療法

腫瘍摘出，骨面削除後，腫瘍と接していた周囲骨全面を液 体窒素を冷媒とする凍結子にて凍結した（矢印）。

いるので，術式選択の参考になると考えられた。その他， 保存的外科療法の一種として河村ら ${ }^{9)}$, 笠原ら ${ }^{10)}$ は, 腫 瘍の摘出とともに腫瘍摘出後の骨再生を促進し下顎の形態 修復をはかる反復処置法を報告している。

一方，上䞄においては，上顎は骨皮質が薄いために腫瘍 が骨膜に拡大しやすく, 眼窩, 翼口蓋窩, 頭蓋底に浸潤す ることがあるため, 上方や後方へ進展したものには健康組 織を含めて en bloc に切除するのが望ましいとする報告が ある30)。自験例においても初回術式が囊胞摘出術で，その 後上方への病巣進展を招いた症例を経験した。

再発症例と X 線像の関係では, 多房性の再発率が高い という報告が多いが31-33), 当科においても同様の結果と なった。しかしながら, 囊胞と術前診断し震胞摘出の術式 を選択した症例により, 単房性の再発も多い結果となっ た。単房性であった 3 例はすべて組織学的には solid/multicystic 型であったので， 単房性の X 線像であっても囊胞 や unicystic 型のエナメル上皮腫と安易に診断してはなら ないことが示唆された。

再発症例の病理組織像を検討すると, follicular 型に再 発が多いとされている ${ }^{8,32,33)}$ 。Hong ら ${ }^{5)}$ は再発と病理組 織型の間には明らかな差があり, follicular, granular cell, acanthomatous 型に再発が多く, desmoplastic, peripheral, plexiform, unicystic 型では再発率は低いとしてい る。follicular 型の組織像を呈するものは浸潤傾向が強い としている報告もある33)。自験例において, 再発症例の各 病理組織像の割合は, 過去の報告の通り solid/multicystic 型が多くを占めたが，その細分類である follicular 型と plexiform 型間の比較では，従来の報告とは逆に後者が多 かった。また, unicystic 型においては luminal 型は再発の 可能性が低く，摘出のみでよいとする意見があるが8, 26), 生検所見のみでは luminal 型と mural 型の区別は困難と考 え, 通常当科では補助療法を併用している。また, 開空療 
法処置を行った 4 例のうち 2 例は X 線上単房性で, 生検 時 unicystic 型と診断した症例であるが, 腫瘍のサイズに 変化がないもしくは増大傾向にあり, さらに, 摘出物病理 標本は solid/multicystic 型であった。そのため, 生検所見 のみで詳細な病理組織型を判定するのは困難であると考え られた。

以下に当科再発症例の治療内容を検証する。症例 1,2 , 3 は, X 線像が単房性のため囊胞と診断し, 生検を施行し ていない。そのため骨面削除と凍結療法を併用せず，隣在 歯の保存も図っており病巣の取り残しをきたしやすい術部 形態となっていたことが再発の理由として考えられた。当 科に扔ける上顎エナメル上皮腫の 3 例中 2 例が症例 1,2 で，再発率は $67 \%$ と高率を示し，上顎は鼻腔や上顎洞が あり形態が複雑で周囲組織に浸潤しやすいため, 手術時の 腫瘍残存を招き再発しやすいといった部位的な問題ととも に，術前診断を襄胞としたことによるものと考えられた。 以上自験例の検討からは，エナメル上皮腫の治療方針とし て術前生検の重要性が考えられた。症例 4,5,6については, 術前にエナメル上皮腫と判断したうえでの再発症例ではあ るが，同様に骨面削除または凍結療法を併用していなかっ たことが再発の原因と考えられた。再発後の治療について は, 症例 2 では上顎であったため 2 次手術は部分切除とし, 症例 1,6 については, 複数回の再発を認め, 最終的には 拡大切除となった。しかしながら症例 $4 ， 5$ に見られるよ うに 2 次手術であっても，早期発見につとめれば，骨面削 除と凍結療法併用の摘出術で制御可能と考えられた。

経過観察に関しては, 10 年以上の経過観察を行う必要 があるという報告 ${ }^{2)}$ や，再発までの期間は数年から十数年 という報告 ${ }^{14)} も あ る 。$ 自験例でも 6 例中 4 例が再発まで の期間が 5 年以上であり, 長期の経過観察の必要性が示唆 された。

\section{結 語}

今回われわれは，当科で経験したエナメル上皮腫につい て臨床病理学的分析を行い, 当科での外科的治療方針の妥 当性について検討したので報告した。

本論文の要旨は第 26 回日本口望腫瘍学会総会・学術大会 (平 成 20 年 1 月，別府市）にて発表した。

\section{文献}

1）森昌彦：歯原性腫瘍. 宮崎 正監修; 口脉外科学, 2 版, 医歯薬出版，東京，2002，217 頁.

2）畑田憲一，野間弘康，他：エナメル上皮腫の治療法に関する 臨床統計的検討. 口沿腫瘍 $11: 143-150,1999$.

3）小崎健一，上田 実，他：エナメル上皮腫の治療と予後に関
する研究. 口科誌 $39 ： 632-640,1990$.

4) Carlson, E.R. and Marx, R.E.: The ameloblastoma: primary, curative surgical management. J Oral Maxillofac Surg 64 : 484-494, 2006.

5) Hong, J., Yun, P.Y., et al.: Long-term follow up on recurrence of 305 ameloblastoma cases. Int J Oral Maxillofac Surg $36: 283-288,2007$.

6) Sachs, S.A.: Surgical excision with peripheral ostectomy: a definitive, yet conservative, approach to the surgical management of ameloblastoma. J Oral Maxillofac Surg 64 : 476-483, 2006.

7) Sampson, D.E. and Pogrel, M.A.: Management of mandibular ameloblastoma: the clinical basis for a treatment algorithm. J Oral Maxillofac Surg $57:$ 1074-1077, 1999.

8）森田章介：下顎エナメル上皮腫の性状ならびに治療法に関す る研究. 日口外誌 $39: 544-559,1993$.

9）河村正昭：顎骨保存法としての反復処置法. 歯科ジャーナル $37: 853-859,1993$.

10）笠原和恵，小林一三，他：歯原性腫崵の臨床的検討。口科誌 $43: 661-671,1994$.

11）狩野岳史，砂川 元，他：エナメル上皮腫の臨床所見と治療 法に関する検討. 琉球医学会誌 $24: 11-17,2005$.

12) Sammartino, G., Zarrelli, C., et al.: Effectiveness of a new decisional algorithm in managing mandibular ameloblastomas: A 10-years experience. Br J Oral and Maxillofac Surg 45 : 306-310, 2007.

13）岡野博郎，森田章介：下顎エナメル上皮腫の擷骨保存療法. 歯科ジャーナル $37:$ 860-864, 1993.

14) Curi, M.M., Dib, L.L., et al.: Management of solid ameloblastoma of the jaws with liquid nitrogen spray cryosurgery. Oral Surg Oral Med Oral Pathol Oral Radiol Endod 84 : 339-344, 1997.

15) Pogrel, M.A. and Montes, D.M.: Is there a role for enucleation in the management of ameloblastoma? Int J Oral Maxillofac Surg $38: 807-812,2009$.

16) Chapelle, K.A., Stoelinga, P.J., et al.: Rational approach to diagnosis and treatment of ameloblastomas and odontogenic keratocysts. Br J Oral Maxillofac Surg $42:$ 381-390, 2004.

17) Lee, P.K., Samman, N., et al.: Unicystic ameloblastoma-use of carnoy's solution after enucleation. Int J Oral Maxillofac Surg $33: 263-267,2004$.

18）古木良彦, 藤田 實, 他：エナメル上皮腫の $\mathrm{X}$ 線学的検討. 口科誌 $37: 179-185,1988$.

19）藤田 實, 和田卓郎：エナメル上皮腫の $X$ 線像. 歯科ジャー ナル $37:$ 579-584, 1993.

20) Gardner, D.G., Heikinheimo, K., et al.: Ameloblastoma. Barnes, L., Eveson, J.W., et al; World Health Organization Classification of Tumours, Pathology and Genetics of Head and Neck Tumours, IARC Press, Lyon, 2005, 296-300.

21）柴原孝彦，森田章介，他：2005 年新 WHO 国際分類による 歯原性腫瘍の発生状況に関する疫学的研究. 口胫腫瘍 20 ： 245-254, 2008.

22）今村晴幸, 向井 洋, 他：エナメル上皮腫に関する臨床的・ 病理組織学的研究. 口科誌 $43: 95-100,1994$.

23) Hasim, F.W., Poon, C.C., et al.: Prolonged survival with confirmed metastatic pulmonary ameloblastoma. Int J Oral Maxillofac Surg 36 : 953-955, 2007.

24）柴原孝彦，森田章介，他：本邦に打けるエナメル上皮腫の病 態と治療法に関する疫学的研究. 口腔腫瘍 $21 ： 171-181$, 
2009.

25）山田隆文：エナメル上皮腫のアンケート結果について（抄）. 口腔腫瘍 $19: 240,2007$.

26）森田章介：エナメル上皮腫に対する顎骨保存療法一摘出・掻 爬術を中心に一-(抄)。口腔腫瘍 19：240-241, 2007.

27）小林一三 : エナメル上皮腫の顎骨保存的療法, 反復処置法 (抄)。口腔腫瘍 $19: 241,2007$.

28）野村武史：エナメル上皮腫の顎骨切除療法（抄)。口腔腫瘍 $19: 241,2007$.

29) Salmassy, D.A. and Pogrel, M.A.: Liquid nitrogen cryosurgery and immediate bone grafting in the management of aggressive primary jaw lesions. J Oral Maxillofac Surg 53 : 784-790, 1995.

30）森田章介, 有家 巧, 他：上顎エナメル上皮腫の臨床統計的 観察. 日口外誌 39:1341-1343, 1993.

31）針谷靖史, 関口 隆, 他：エナメル上皮腫 79 例の臨床病理 学的検討. 口腔腫瘍 9:101-107, 1997.

32）大亦哲司, 森田展雄, 他：エナメル上皮腫の臨床病理学的研 究. 口腔腫瘍 $8: 16-24,1996$.

33）佐藤 明, 中島純一, 他：下顎骨エナメル上皮腫の臨床・組 織所見及び治療法の検討. 口腔腫瘍 8：45-53, 1996. 


\title{
A clinical study of the surgical treatment for ameloblastoma and its recurrence
}

\author{
Shoko Yoshida ${ }^{1)}$, Goichi Tsukamotol), Norie Yoshioka ${ }^{1)}$, \\ Tsuyoshi Shimo $^{1)}$, Koji Kishimoto ${ }^{1)}$, Akiyoshi Nishiyama ${ }^{1)}$, \\ Kazuhiko Ohyama ${ }^{2)}$, Hiroshi Mese ${ }^{1)}$, Hitoshi Nagatsuka ${ }^{3)}$ \\ and Akira Sasaki ${ }^{1)}$ \\ 1) Department of Oral and Maxillofacial Surgery, Okayama University Graduate \\ School of Medicine, Dentistry and Pharmaceutical Sciences \\ (Chief: Prof. Akira Sasaki) \\ 2) Ako Hakuhoukai Hospital, Department of Dentistry and Oral Surgery \\ (Chief: Dr. Kazuhiko Ohyama) \\ 3) Department of Oral Pathology and Medicine, Okayama University Graduate \\ School of Medicine, Dentistry and Pharmaceutical Sciences
}

(Chief: Prof. Hitoshi Nagatsuka)

\begin{abstract}
The management of ameloblastoma still remains controversial. Principally, in cases where there was no or little perforation of the surrounding bone, we chose conservative surgical management that is an extirpation with peripheral osteotomy and cryotherapy of the internal bone surface. In this report the treatment histories of 50 cases of ameloblastoma, especially recurrent cases, from 1982 to 2007 at our department were investigated clinicostatistically.

Of the 50 cases, we performed extirpation on 12 cases, extirpation with peripheral osteotomy and/or cryotherapy (extirpation with assistant therapy) on 21 cases and dissection (marginal or partial dissection of the jaw) on 17 cases. The recurrence rate was 12\% (6 of 50 cases). Five recurrent cases received extirpation (recurrence rate: $42 \%$ ) and one case received extirpation with assistant therapy (recurrence rate: 6\%). The dissection caused no recurrent cases. There was a significant difference between extirpation with and without assistant therapy in the recurrence rate as well as between extirpation and dissection.

These results suggested that the procedures of peripheral osteotomy and cryotherapy in conservative surgical management for ameloblastomas is useful for controlling the lesion.
\end{abstract}

Key words : ameloblastoma, recurrence, clinicostatistical study, conservative surgical management

Requests for reprints to: Dr. Yoshida S., Department of Oral and Maxillofacial Surgery, Okayama University Graduate School of Medicine, Dentistry and Pharmaceut Sciences, 2-5-1 Shikata-cho, Kita-ku, Okayama, 700-8525, Japan 